Vanja Trifunović ${ }^{1 *}$

${ }^{1}$ Mining and Metallurgy Institute Bor, Bor, Serbia
Rewiev paper

ISSN 0351-9465, E-ISSN 2466-2585

UDC: $620.192 .41: 628.516: 502.175$

https://doi.org/10.5937/zasmat2103166T

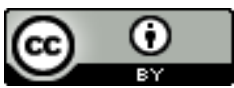

Zastita Materijala 62 (3)

166 - 179 (2021)

\title{
Vitrification as a method of soil remediation
}

\begin{abstract}
Various types of contaminated soil and hazardous waste that have a negative impact on the environment and human health can be treated with the vitrification process. This process is based on thermal treatment of contaminated soil or waste at high temperatures, with the addition of additives, whereby the soil/waste melts and a stable glass is formed. The resulting glass and glass-ceramic products have good mechanical resistance, chemically are resistant and immobilize contaminants, thus preventing their further negative impact on the environment. This paper presents a literature review of the vitrification process of different types of contaminated soil and hazardous waste.
\end{abstract}

Keywords: vitrification, contaminated soil, waste, environment protection.

\section{INTRODUCTION}

Pollution of the environment with various organic and inorganic substances is one of the biggest problems in the world. Environmental problems stem from human activities, such as exploitation and leaching of ores and industrial activities. These activities lead to contamination of air, water resources and soil, with organic and inorganic substances. Care for the environment has resulted in the development of many new technological processes for the treatment of solid, liquid and gaseous waste during industrial production, in order to reduce the emission of pollutants into the environment [1-12].

Contamination of the environment as a whole has not spared any of its components, as is the case with the soil itself, which is a very important component of it. The seriousness of this problem is reflected in the fact that soil damage and destruction can result in negative effects on other parts of the ecosystem, such as the hydrological regime of the environment, the diversity of plant and animal species and similarly $[13,14]$.

*Corresponding author: Vanja Trifunović

E-mail: vanja.trifunovic@irmbor.co.rs

Paper received: 19. 11. 2020.

Paper corrected: 20. 05. 2021.

Paper accepted: 24. 05. 2021.

Paper is available on the website: www.idk.org.rs/journal
Heavy metals such as $\mathrm{Pb}, \mathrm{Cu}, \mathrm{Zn}, \mathrm{Cd}, \mathrm{Ni}, \mathrm{Co}$, $\mathrm{Hg}, \mathrm{Cr}$, etc., represent one of the largest groups of contaminants. They can be found in nature, most often in water and soil, as a consequence of ore exploitation and processing, industrial production, urban activities, use of artificial fertilizers in agriculture, etc. Heavy metals are very toxic, nonbiodegradable and tend to accumulate in living organisms. With the change of physical and chemical parameters of the environment, heavy metals are leached from various industrial waste and industrial intermediates, which leads to contamination of groundwater and surface water, and thus they become available to living organisms. In this way, soil and sediments appear as potential sources of pollution, that is, reservoirs of heavy metals. Soil remediation is of great importance for the environment, and requires large investments [1, 3, 13, 15].

Sanation or remediation of soil is a procedure that reduces or removes contaminants from soil, in that measure that its contents allow the use of soil from the rehabilitated site. A large number of technologies for the remediation treatment of contaminated soil have been developed. Potentially possible and economically acceptable remediation technologies are: biological (bioremediation and phytoremediation), chemical (electrochemical, soil washing, soil flooding, solidification and natural cleaning), physical (encapsulation, excavation and soil mixing) and thermal remediation (incineration, 
vitrification of soil and solar-photochemical soil decomposition). Which of the remediation technologies will be applied to the contaminated soil depends on the following parameters: type, sort and amount of pollutant, spatial contamination, soil type (soil reactions, organic matter content, proportion and type of clay), time of exposure to pollution, future use of soil, legally prescribed degrees of sanation (remediation). Based on all the previously mentioned parameters, the remediation site is also selected $[1,6,16-19]$. According to the location where remediation process is performed, the techniques are divided into ex situ and in situ $[3,20,21]$.

\section{SOIL REMEDIATION BY THE PROCESS OF VITRIFICATION}

The method of vitrification, is one of the most promising techniques for treating contaminated soil and solid industrial waste. The technology is based on heat treatment of contaminated soil at temperatures of $1400-2000^{\circ} \mathrm{C}$, and sometimes even higher, whereby the soil melts and a stable glass or glass-ceramic material (vitreous material) is formed, which drastically reduces their solubility and destroys organic compounds [1, 5, 15, 22-31]. Some of the materials on which this process can be applied are: municipal waste, dust from electric arc furnaces, hydrometallurgical waste of zinc, drainage sludge and granite sludge, tailings, fly ash from thermal power plants, nuclear waste, ash from the leather industry, etc. [30, $32-46]$.

Waste is a mixture of different substances that have the possibility to form glass when melted. If the waste does not contain some of those substances, they can be added during melting process. Additives that can be added are: glass formers: $\mathrm{SiO}_{2}, \mathrm{~B}_{2} \mathrm{O}_{3}, \mathrm{GeO}_{2}, \mathrm{P}_{2} \mathrm{O}_{5}, \mathrm{~V}_{2} \mathrm{O}_{5}$ and $\mathrm{As}_{2} \mathrm{O}_{3}$, intermediates which can't form glasses on their own, but aid with other oxides to form glasses: $\mathrm{Al}_{2} \mathrm{O}_{3}, \mathrm{Sb}_{2} \mathrm{O}_{3}, \mathrm{ZrO}_{2}, \mathrm{TiO}_{2}, \mathrm{PbO}, \mathrm{BeO}, \mathrm{ZnO}$, and glass modifiers: $\mathrm{MgO}, \mathrm{Na}_{2} \mathrm{O}, \mathrm{K}_{2} \mathrm{O}, \mathrm{CaO}$ etc. which modify glass and can improve the encapsulation of pollutants and reduce their possibility of leaching $[23,24,31,34,47-50]$.

The vitreous material formed in the process provides satisfactory chemical stability (it is resistant to the leaching of "trapped" contaminants), immobilizes toxic elements (heavy metals) in the glass structure and decomposes dioxins. This is of great importance, because solid industrial waste usually has a very complex chemical composition [14, 24, 25, 47, 49, 51, 52]. Thus, metals and hazardous waste components can be immobilized through two main interactions with the glass matrix: chemical bonding and encapsulation. The vitrification process leads to a significant reduction in the volume of waste, which has significant advantages in terms of storage or disposal. However, despite the advantages, this advanced immobilization technique has very high costs, so its application is justified mainly when it is difficult to use cheaper methods for inertization of waste and/or when value-added materials can be obtained $[14,24,25,47,49,51-53]$. The agentcosts of vitrification treatment range from $1000 € / \mathrm{m}^{3}$ and up [54]. However, the cost of the process may be lower than the cost of disposing of the waste at the landfill, and there is a possibility of reusing the resulting vitrification product, so the costs can be reduced because the waste after the process has some value $[15,49,53]$.

Vitrification as a method of remediation of soil contaminated with heavy metals and solid industrial waste is usually performed in the following ways:

- electrical process - in situ process, where electricity is supplied to graphite electrodes imprinted in contaminated soil;

- thermal process in the furnace - ex situ process performed in special reactors, which are usually rotary furnaces lined on the inside with refractory material;

- plasma process - usually in situ process, which is performed by guiding plasma burners into contaminated soil, and the plasma temperature is extremely high (up to $7000^{\circ} \mathrm{C}$ ), on wich soil and pollutants are melting [16, 28, 55].

This method of remediation is the most efficient and most widely used method in cases of contamination with substances of inorganic origin. It is very often also used for the treatment of soil contaminated with metals and radionuclides, because by glazing they are trapped and their release into deeper parts of the soil is prevented $[16,34,36,53]$.

With the vitrification technique, it is possible to obtain monolithic glasses, which can be transformed into glass-ceramics by controlled thermal treatments, especially wollastonite $\left(\mathrm{CaO} \cdot \mathrm{SiO}_{3}\right)$, anorthite $\left(\mathrm{CaO} \cdot \mathrm{Al}_{2} \mathrm{O}_{3} \cdot 2 \mathrm{SiO}_{2}\right)$, diopside $\left(\mathrm{CaO} \cdot \mathrm{MgO} \cdot 2 \mathrm{SiO}_{2}\right)$ and iron oxides $\left(\mathrm{Fe}_{2} \mathrm{O}_{3}, \mathrm{Fe}_{3} \mathrm{O}_{4}\right)$. These glasses may be suitable for potential reuse in new products and / or as coating materials with high chemical and mechanical resistance for use in the construction industry $[11,15,49,52,56]$.

\subsection{In situ vitrification}

In situ vitrification turns buried waste and contaminated soil at their original location, without any excavation or transport, into an extremely durable form of glass and crystalline waste that is non-hazardous. These techniques are minimally destructive to the site and the costs of their use are lower compared to ex situ techniques. In situ 
vitrification has a number of advantages over other technologies, especially due to its ability to treat mixed waste, including soil with buried waste or tanks, dried sludge, tailings, sediments, organic waste, chemical waste, radioactive waste, and mixtures of hazardous and radioactive waste [16, $19,22,25,35,36,47,51,55,57-64]$. The application of in situ techniques depends on the type of pollution, the conditions prevailing in the contaminated medium as well as the conditions prevailing at that location $[20,21]$.

In this process, the soil is heated by applying an electric current to four electrodes inserted into the contaminated soil in a square shape. The electrodes consist of an inner core of molybdenum with a diameter of $5 \mathrm{~cm}$ inside a graphite tube with a diameter of $30 \mathrm{~cm}$. The graphite tube provides a relatively inexpensive cross-section that accelerates the conduction of current into the melt, and also provides a protective layer for the molybdenum inner electrode. When the process is finished, the graphite tube is sacrificed because it is left in the melt, while the more expensive inner electrode can be reused, which provides cost savings [21, 22, 59, 65].

Melting of the soil takes place with a cold cap, ie. by a batch layer floating on the surface of molten glass [66]. The electrode design has been developed to help the cold cap go down as low as possible and to achieve reliable electrode performance throughout the entire individual adjustment (up to $400 \mathrm{~h}$ ). The lowering of the cold cap refers to the suppression of the porous glass layer that tends to form on the surface of melt [59].

The electrodes are placed in the soil to the desired depth of processing, and since most of the soil is initially non-conductive, a specially prepared mixture of graphite and glass frit (crushed glass) called starter, is placed between the electrodes on the surface of the soil to begin the melting process. The application of electric current heats the starter path and the surrounding soil to $2000^{\circ} \mathrm{C}$, well above the initial soil melting temperature of 1100 $1400^{\circ} \mathrm{C}$. The high temperature leads to the melting of the soil layer, thus establishing a molten, conductive path that is transferred to the soil mass. This molten zone continues to grow and is transferred to the soil mass until it gains sufficient strength to overcome heat loss. In general, the melt grows externally at about $50 \%$ of the electrode spacing $[22,59]$. The in situ vitrification system on the field scale melts the soil at a rate of 4-6 t/h. Accordingly, the rate of melting progress is in the range of $25-50 \mathrm{~mm} / \mathrm{h}[22,25]$. The shape of the melt is roughly a cube with slightly rounded corners, a shape that reflects a higher power density around the electrodes [59].
As the thermal gradient progresses in the soil, solid and liquid organic pollutants first evaporate and then pyrolyze (i.e. decompose in the absence of oxygen) into their elemental components. The gaseous by-products of organic pyrolysis move slowly through the melt towards the upper surface of the melt. Some of these gases dissolve in the molten mass, but the remain that "escapes" is collected in the waste gas collection hood for further processing in the waste gas purification system [22, 25]. The entire area to be treated is covered with a hood to collect all the waste gases produced during the vitrification process. The hood over the process site is maintained at a slightly negative pressure of $125-250 \mathrm{kPa}$ to retain any gas or particles that can be released. If a high concentration of solid or liquid organic constituents is present in the contaminated soil, the waste gases can reach a temperature of $750^{\circ} \mathrm{C}$. The gases collected in the hood are cooled and directed to the waste gas purification system [21, $22,57,58,65]$.

Although in situ vitrification is a widely applicable method of soil remediation, there are limitations to its application, such as geometry, soil variations, moisture, foreign material inclusions, and criticality. For example, as the soil, wet soil and groundwater are heated in the process, the water reaches the boiling point and the process cannot proceed until all the water has boiled and evaporated. That can cause significant electricity consumption just for water evaporation. This additional heat load reduces the amount of energy available for melting, which reduces the rate of soil melting and can reduce the maximum depth that can be achieved by in situ vitrification process [21, $22,54]$. Some soils with a concentration of organic chemicals greater than 5-10 wt.\% will cause an overload in the gas purification system [22, 29, 59].

The in situ vitrification process can also receive a significant amount of scraps, debris or other inclusions within the treated area [22].

\subsubsection{Application of in situ vitrification process}

In 1981, the Pacific Northwest Laboratory (PNL) [21] developed an in situ vitrification process to solidify radioactive transuranic waste. For demonstration and developing the process, two scales of non-radioactive experiments were used. The laboratory test unit of engineering scale, which uses two electrodes with a distance of $36 \mathrm{~cm}$, vitrified $45 \mathrm{~kg}$ of soil per test, and the pilot test system, which uses four electrodes in a square sample of $1.2 \mathrm{~m}$, successfully fixed up to $10000 \mathrm{~kg}$ of soil. Based on the obtained results, a full-scale in situ vitrification reference system was defined. 
The thermal process that first involves the use of high-power currents that pass through the material that melts, then turns off and the material cools quickly is also called Joule heating vitrification. This vitrification procedure was successfully developed by the Pacific Northwest Laboratory (PNL) for the US Department of Energy (DOE) $[27,65]$.

Dellisanti et al. [27] reported in their work the details of vitrification with the Joule heating effect carried out using a specially designed pre-pilot scale plant for asbestos-containing materials and soil. The asbestos-containing material was encapsulated in uncontaminated soil, and its vitrification was performed in a steel container. The two electrodes were placed at a distance of $30 \mathrm{~cm}$ and between them a starter made of a mixture of unpolluted soil and graphite flakes. Average delivered power was $20 \mathrm{~kW}$, which resulted in an average current of about $130 \mathrm{~A}$. The maximum depth of penetration of the mobile electrodes into the ground was $30 \mathrm{~cm}$. It took about $5 \mathrm{~h}$ to achieve complete melting of the material in temperature about $1600^{\circ} \mathrm{C}$. The resulting vitreous product was cooled for about $24 \mathrm{~h}$ until it reached room temperature. The total vitrified mass was about 100 $\mathrm{kg}$, and the vitrified volume was $55 \mathrm{~cm} \times 50 \mathrm{~cm} \times$ $40 \mathrm{~cm}$, which means that all asbestos-containing material was placed in a steel container and distributed in uncontaminated soil embedded in monolithic glass. During process there was a reduction in soil volume of about $25 \%$. X-ray Diffraction (XRD) analysis determined that the asbestos minerals were completely melted and incorporated into a glassy monolith or converted into high-temperature harmless silicates (enstatite and diopside).

In their next work, Dellisanti et al. [65] presented a method of remediation of several tons of ceramic waste rich in $\mathrm{Pb}$ and $\mathrm{Zn}$ based on vitrification of Joule heating. The waste was the sludge of the ceramic industry in the process of tile enameling and is characterized by the content of $2.85 \% \mathrm{~Pb}, 2.98 \% \mathrm{Zr}$ and $0.75 \% \mathrm{Zn}$. XRD analysis showed that $\mathrm{Pb}$ was present in the waste as lead silicate (alamosite) and $\mathrm{Zr}$ as zirconium silicate (zircon), while $\mathrm{Zn}$ appeared as a dissolved element or in mineral phases. Waste also contained quartz, plagioclase, calcite and layered silicates (mica and kaolinite). X-ray fluorescence analysis (XRF) showed that the starting waste material contained $55.99 \% \mathrm{SiO}_{2}, 11.41 \% \mathrm{Al}_{2} \mathrm{O}_{3}, 4.02 \% \mathrm{Fe}_{2} \mathrm{O}_{3}, 0.63 \%$ $\mathrm{TiO}_{2}$ and $12.64 \% \mathrm{CaO}$. The in situ vitrification plant consisted of four main parts: (1) a high power generator made of a Scott transformer (threephase/two-phase); (2) four identical graphite electrodes $(150 \mathrm{~cm}$ long and $10 \mathrm{~cm}$ in diameter) for supplying current to the ground; (3) waste gas collection system; and (4) a wastewater treatment system consisting of a filtration and treatment plant. The average delivered power was $450 \mathrm{~kW}$ which resulted in an average current of about $300 \mathrm{~A}$. The electrodes were mobile and could be lowered by the motor during the process while the base melted and the maximum depth of penetration into the ground was $120 \mathrm{~cm}$. By heating to about $1850^{\circ} \mathrm{C}$, the waste material was completely melted, and the amount of 15 tons of monolithic glass was formed by rapid cooling of the melt. The monolith occupied an area of $200 \times 200 \mathrm{~cm}$ and reached a depth of $130 \mathrm{~cm}$. Mineralogical, morphological and chemical analyzes showed that the obtained glassy material was very homogeneous. Alkalinity tests confirmed that hazardous metals $(\mathrm{Pb}, \mathrm{Zn}$ and $\mathrm{Zr})$ were immobilized in a vitrified monolith indicating high durability and chemical resistance of the glass [65].

\subsection{Ex situ vitrification}

Ex situ vitrification technology is designed to inactivate and/or immobilize pollutants at locations away from contaminated soil/waste landfills, transforming them into a glass mass of molten soil in furnaces (chamber or rotary) at high temperatures. The resulting vitreous material has a high strength and is resistant to the release of pollutants contained in it, and thus prevents its dissolution, migration into groundwater or any impact on the environment, as is the case in the in situ process [16]. Immobilization degree of heavy metals in vitreous materials formed in the process is examined by leachability and toxicity tests [49, 53]. Depending on the type of vitrification process, the resulting molten mass can be abruptly cooled (quenching) or allow to cool slowly in air [16].

\subsubsection{Application of ex situ vitrification process}

The ex situ vitrification process is performed mainly when the waste to be vitrified does not contain sufficient amounts of oxides to form glass, and when it is necessary to add them, and this is not possible at the location where the waste is located.

Kavouras et al. [47] applied the ex situ vitrification method to stabilize solid waste rich in lead and iron oxides, ie. ash produced by the combustion of sludge obtained from storage tanks for tetraethyl lead (TEL) and leaded gasoline. The composition of the ash was as follows: $33.0 \% \mathrm{Fe}$, $29.6 \% \mathrm{~Pb}, 10.1 \% \mathrm{Br}, 1.0 \% \mathrm{Si}, 0.25 \% \mathrm{~S}, 0.8 \% \mathrm{Al}$, $0.3 \% \mathrm{Sb}$. Before melting, certain amounts of additives $\left(\mathrm{SiO}_{2}\right.$ and $\left.\mathrm{Na}_{2} \mathrm{CO}_{3}\right)$ were added to the ash. Melting was performed in a platinum pot, in an oven, at $1400^{\circ} \mathrm{C}$. The resulting melt was quenched (cooled) on a stainless steel plate at room temperature. The vitrified product consisted of 60 
wt.\% of solid waste (ash), 25 wt. \% of $\mathrm{SiO}_{2}$ and 15 wt.\% of $\mathrm{Na}_{2} \mathrm{O}$. The test results showed that this type of final product may be suitable for safe ash disposal, because the chemically resistant amorphous crust covers its inhomogeneous interior. However, it cannot be crushed by grinding so that, for example, it can be used for road stones, due to the fact that parts of the matrix would be exposed to the environment and toxic elements would be leached. If the melt was poured over the granulator, gravel material would be produced, which would solve the problem.

Chromium salts (especially chromium sulfate) are the most commonly used tanning substances in the leather industry today. Vitrification of hazardous waste generated from the chromium-tanned leather industry, ie. chromium rich ash, was applied by Basegio et al. [49]. Chemical analysis determined the chromium oxide content of 29.4 wt. \%, of which only $2.5 \%$ of chromium was hexavalent. Vitrification was applied to original ash samples and ash samples mixed in different ratios with sodium-lime glass and $\mathrm{TiO}_{2} / \mathrm{MgO}$ oxide. The samples were then annealed at $750,800,950$ and $1000^{\circ} \mathrm{C}$ for 2 hours. Different ratios of aditives and ash were used to test the immobilization of chromium in the obtained vitreous material. The degree of chromium immobilization in vitreous ceramic bodies was estimated by leaching tests (toxicity tests). Also, an estimation of gas emissions during annealing was done in order to determine the possibility of any losses of chromium during gas emissions. For formulations containing ash and sodium-lime glass, when $\mathrm{MgO}$ was added as an additive, immobilization of chromium ions was achieved. Immobilization of chromium in ceramic bodies was more efficient at higher annealing temperatures, which leads to a decrease in the leaching rate of chromium. Data on gas emissions confirmed that it was not possible to observe the evolution of chromium by gas emissions during the annealing of ceramic bodies.

Treatment of chromium-rich waste was also examined by Varitis et al. [53]. Chromium-rich ash is obtained as a by-product of burning sludge obtained from tanning leather. Sludge was pretreated first to remove as much organic matter as possible, and to avoid oxidation of chromium from the trivalent to the hexavalent form because hexavalent chromium and its compounds are toxic when inhaled or ingested. The pre-treatment consisted of annealing the sludge for 90 minutes at $500^{\circ} \mathrm{C}$, after which six different batch compositions were made with a mixture: silicon dioxide $\left(\mathrm{SiO}_{2}\right)$, soda $\left(\mathrm{Na}_{2} \mathrm{CO}_{3}\right)$ and lime $(\mathrm{CaO})$ in different proportions as shown in Table 1.

\section{Table 1. Conditions of experiments}

Tabela 1. Uslovi eksperimenata

\begin{tabular}{|c|c|c|c|c|c|c|}
\hline \multirow{2}{*}{ Sample } & \multicolumn{4}{|c|}{ Batch mixtures (wt.\%) } & \multirow{2}{*}{ Vitrification temperature $\left({ }^{\circ} \mathrm{C}\right)$} & \multirow{2}{*}{ Time (h) } \\
\hline & Ash & $\mathrm{SiO}_{2}$ & $\mathrm{Na}_{2} \mathrm{O}$ & $\mathrm{CaO}$ & & \\
\hline 1 & 20 & 55 & 15 & 10 & 1400 & 2 \\
\hline 2 & 15 & 55 & 15 & 15 & 1400 & 2 \\
\hline 3 & 13 & 50 & 10 & 27 & 1400 & 2 \\
\hline 4 & 13 & 56 & 7.5 & 23.5 & 1400 & 2 \\
\hline 5 & 13 & 56 & 5 & 26 & 1500 & 2 \\
\hline 6 & 10 & 55 & 15 & 20 & 1400 & 2 \\
\hline
\end{tabular}

The mixtures were melted for 120 minutes in a platinum crucible at $1400^{\circ} \mathrm{C}$ and $1500^{\circ} \mathrm{C}$, depending on the batch composition, to achieve a homogeneous melt. The melt was cooled rapidly after it was poured onto a stainless steel refractory plate. Vitrified products (monoliths) were either composed of silicate matrices with separate crystallites of molten eskolaite $\left(\mathrm{Cr}_{2} \mathrm{O}_{3}\right)$ or were homogeneous glass (in one case). All vitrified products were subsequently heat treated to encourage crystallization and produce devitrified products. The vitreous nature of vitrified products and the corresponding heat treatment temperatures were determined by Differential Thermal Analysis (DTA), while the characterization of vitreous products was performed by XRD analysis, Scanning Electron Microscopy (SEM) and Energy-Dispersive X-ray Spectroscopy (EDS). In devitrified products, crystallization led to the separation of the crystalline phases of devitrite $\left(\mathrm{Na}_{2} \mathrm{Ca}_{3} \mathrm{Si}_{6} \mathrm{O}_{16}\right)$, combeite $\left(\mathrm{Na}_{4} \mathrm{Ca}_{4} \mathrm{Si}_{6} \mathrm{O}_{18}\right)$ and wollastonite $\left(\mathrm{CaSiO}_{3}\right)$, while heat treatment did not affect the escolate crystallites. The alkalinity test of the obtained vitreous materials according to the 
standard EN 12457-4 was also performed. The test results revealed that in the vitrified monolith successfully stabilized chromium and that devitrification reduces stabilization of chromium only in the case when the initial vitrified product was homogeneous glass [53].

Karamanov et al. [51] used metallurgical waste from a ferronickel smelter in Macedonia in their research. Three types of hazardous residues from the ferronickel smelter (filter dust, slag from the electric furnace and slag from the converter) were mixed with broken glass and vitrified for 2 hours at $1400^{\circ} \mathrm{C}$. The crystallization process was very special due to the presence of $1.5 \mathrm{wt} \%$ chromoxide in the parent glass, together with large amounts of iron oxide and magnesium oxide. It begins during the cooling of the melt with the deposition of preliminary crystals of $\mathrm{Fe}-\mathrm{Mg}-\mathrm{Cr}$ spinel, which then act as centers for further epitaxial growth of the pyroxene phase. The obtained glass is characterized by very good mechanical characteristics, high chemical durability, and a suitable coefficient of thermal expansion.

Ballesteros et al. [9, 11] used toxic sodium chromate sludge enriched with $\mathrm{Cr}^{6+}$ chromium from an industrial area in the city of Tultitlan, Mexico, in their studies of the vitrification process. A mixture of $75 \mathrm{wt} . \%$ dry sludge, $25 \mathrm{wt} . \%$ feldspar and $5 \mathrm{wt} . \%$ coke ash was melted for $8 \mathrm{~h}$ at $1450^{\circ} \mathrm{C}$. The results of XRD and SEM/EDS analyzes showed the formation of the following crystal phases: chromium, iron and aluminum spinel ( $\mathrm{Mg}, \mathrm{Fe})(\mathrm{FeAlCr})_{2} \mathrm{O}_{4}$, phases hematite $\left(\mathrm{Fe}_{2} \mathrm{O}_{3}\right)$, magnetite $\left(\mathrm{Fe}_{3} \mathrm{O}_{4}\right)$, pyroxene $[\mathrm{Ca}(\mathrm{Mg}), \quad \mathrm{Al})\left[(\mathrm{Si}, \mathrm{Al})_{2} \mathrm{O}_{6}\right]$ and augite $[\mathrm{Ca}(\mathrm{Mg}$, $\left.\mathrm{Fe}) \mathrm{Si}_{2} \mathrm{O}_{6}\right]$.

Kimura et al. [67] simulated zeolite waste vitrified into borsilicate glass with the addition of additives $\mathrm{H}_{3} \mathrm{BO}_{3}, \mathrm{Na}_{2} \mathrm{CO}_{3}$ or $\mathrm{Na}_{2} \mathrm{~B}_{4} \mathrm{O}_{7}$ at a melting point of $1100^{\circ} \mathrm{C}$ to $1300^{\circ} \mathrm{C}$ for a period of 3 hours. The results showed that the obtained glass products were in a completely amorphous state.

In the vitrification process of radioactive liquid waste, the waste is brought to the top of a pool of molten glass contained in equipment called Joule Heated Ceramic Melter (JHCM) [35, 36, 61, 65, 66, 68]. In the work of Goel et al. [61], the treatment of radioactive waste obtained from plutonium production and the melting rate of batch material were investigated. The melting rate of the charged material, depending on the properties of the raw material and the operating conditions of the melting furnace, can be calculated using the heat transfer properties of the cold cap [61]. The batch in the form of a suspension is charged from above, creating a cold cap on the surface of the molten glass that covers $90-95 \%$ of the furnace surface.
The cold cap is a cover of the same thickness that receives even amounts of heat both from the molten glass from below and from the plenum space from above. As the batch moves through the cold cap, chemical reactions and phase transitions occur, through which the batch turns into molten glass that moves downward from the cold cap [36, $61,62,69,70]$. Upon melting, each batch particle travels vertically downward through the cold cap, and its properties (e.g., density, dissolution rate of solids, reaction kinetics) change in response to increasing temperature [61]. Different reactions of the cold cap develop gases that come out of the cold cap through open pores. A small amount of residual gases can remain in the glass-forming melt and cause foaming. The foam reduces heat transfer from the molten glass to the cold cap, reducing the melting rate [62].

To improve heat transfer to the cold cap, forced convection is caused by gas bubbles in the melt, which increases the melting rate because increased convection brings hot glass from the bottom of the furnace near the cold cap, with increased fluid velocity the thickness of the boundary layer near the bottom sides of the cold cap and also by increased convection and large bubbles of foam is achieved the removal of bubbles of insulating gas that form at the bottom of the cold cap. When the process is complete, the furnace temperature drops to $850-900^{\circ} \mathrm{C}$, and then crystal types such as spinel are formed. Once formed, spinel deposits are difficult to dissolve because they are stable at temperatures much higher than operating temperatures $\left(1150-1200^{\circ} \mathrm{C}\right)$ [61].

Rincón et al. [2] considered the vitrification of a combination of waste from abandoned vermiculite deposits, lithium-aluminum-phosphate amblygonite, mineral waste, and sodium borate. The melting process of a mixture of vermiculite-amblygonite (marked as Va1) and vermiculite-sodium borate (marked as Va2) was performed for 2 hours at $1400^{\circ} \mathrm{C}$ in an furnace. After pouring into brass molds, the glasses were cooled by thermal heating to $500^{\circ} \mathrm{C}$ for one hour to room temperature. The resulting glasses were green in color, transparent and smooth, which in the case of Va1 glass can give glass ceramics with an iridescent surface or a metal-like effect. Glass obtained by mixing vermiculite with commercial sodium borate showed a lower tendency to crystallize compared to that obtained by mixing vermiculite with ambligonite. Complete characterization of the obtained glass was performed by analysis of XRD, EDS, X-ray Photoelectron Spectroscopy (XPS) and the method of Hot Stage Microscopy (HSM) on the basis of which it was concluded that the main formed crystal phases are $\alpha$-cordierite and $\beta$-spodumene. 
The surface of this glass-ceramic made of vermiculite amblygonite is enriched with $\mathrm{Fe}_{2} \mathrm{O}_{3}$. The relative variation in viscosity was determined by the HSM method on both $\mathrm{Va} 1$ and $\mathrm{Vb} 1$ glasses. This method determined that the tendency of crystallization on heating will be higher for glass Va1 than for glass Vb1.

Research on vitrification of organic waste (palm compost and palm leaf residues, volcanic lava used in local agriculture, natural organic peat, humus and sewage sludge) was performed by Jordan et al. [23]. The results of XRF analysis showed that all tested samples contain the main components for glass formation $\left(\mathrm{SiO}_{2}, \mathrm{~K}_{2} \mathrm{O}, \mathrm{CaO}\right.$, $\mathrm{MgO}, \mathrm{Al}_{2} \mathrm{O}_{3}, \mathrm{Fe}_{2} \mathrm{O}_{3}$ and $\mathrm{P}_{2} \mathrm{O}_{5}$ ) but in insufficient quantities. Although the content of these components is lower, it is concluded that the tested samples in combination with some other waste could be used to obtain glass and glass-ceramic products.

A study by Stabile et al. [52] includes the chemical characterization of bottom ash derived from municipal solid waste produced at a combustion plant in Rimini, Italy, and experimental investigations of vitrification process in which special attention is paid to the behavior of volatile metal components (e.g. Zn, As, Cd, etc.). Experimental tests were performed on a laboratory scale under atmospheric conditions. Melting of the ash was performed in a platinum pot in a chamber furnace at temperatures of $1000^{\circ} \mathrm{C}$ and $1100^{\circ} \mathrm{C}$, for process times of $1 \mathrm{~h}, 2 \mathrm{~h}, 4 \mathrm{~h}, 8 \mathrm{~h}$ and $16 \mathrm{~h}$. After melting, the pot removed from the oven was quickly cooled by immersion in a water bath. Electron Micro-Probe (EMP) analysis was used to examine the homogeneity of the samples and to obtain quantitative chemical data on the main amounts of metal oxides in the cooled glasses produced in the bottom ash vitrification experiments. Based on the obtained analysis, it can be concluded that the vitrified samples obtained by melting methods represent a homogeneous glass structure of dark vitreous appearance. Table 2 shows the conditions under which the process was performed, as well as the main oxide composition of the ash.

Table 2. Process conditions and main oxide compositions in tested samples

Tabela 2. Uslovi procesa i glavni sastav oksida u ispitivanim uzorcima

\begin{tabular}{|c|c|c|c|c|c|c|c|c|c|c|c|c|c|c|}
\hline \multirow{3}{*}{ 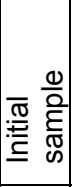 } & \multirow{3}{*}{ 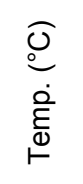 } & \multirow{3}{*}{ 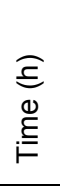 } & \multicolumn{11}{|c|}{ Chemical composition (wt.\%) } & \multirow{2}{*}{$\begin{array}{c}\text { Physical } \\
\text { appearan } \\
\text { ce } \\
\end{array}$} \\
\hline & & & $\mathrm{SiO}_{2}$ & $\mathrm{TiO}_{2}$ & $\mathrm{Al}_{2} \mathrm{O}_{3}$ & $\mathrm{FeO}^{*}$ & $\mathrm{CaO}$ & $\mathrm{MnO}$ & $\mathrm{MgO}$ & $\mathrm{K}_{2} \mathrm{O}$ & $\begin{array}{c}\mathrm{Na}_{2} \\
\mathrm{O}\end{array}$ & $\begin{array}{c}\mathrm{P}_{2} \mathrm{O} \\
5 \\
\end{array}$ & Total & \\
\hline & & & 46.05 & 0.83 & 9.31 & 16.31 & 17.20 & 1.13 & 2.70 & 0.96 & 5.48 & 0.58 & 100.55 & $\begin{array}{c}\text { Gray, } \\
\text { inhomog. }\end{array}$ \\
\hline 1 & 1000 & 1 & 42.52 & 0.17 & 5.60 & 4.66 & 30.76 & 0.17 & 3.41 & 0.56 & 5.60 & 0.38 & 98.83 & $\begin{array}{c}\text { Gray, } \\
\text { inhomog. }\end{array}$ \\
\hline 2 & 1000 & 2 & 42.92 & 1.67 & 8.96 & 18.18 & 20.14 & 0.10 & 3.13 & 1.03 & 2.80 & 1.13 & 100.06 & $\begin{array}{c}\text { Gray, } \\
\text { inhomog. }\end{array}$ \\
\hline 3 & 1000 & 4 & 50.88 & 0.51 & 7.05 & 6.38 & 24.51 & 0.09 & 3.17 & 1.11 & 4.95 & 0.32 & 7 & $\begin{array}{c}\text { Black, } \\
\text { inhomog. }\end{array}$ \\
\hline 4 & 1000 & 8 & 71.68 & 0.22 & 1.91 & 1.71 & 11.09 & 0.12 & 2.62 & 1.62 & 7.08 & 0.01 & 98.06 & $\begin{array}{c}\text { Black, } \\
\text { inhomog. }\end{array}$ \\
\hline 5 & 1000 & 16 & 60.43 & 0.50 & 9.32 & 4.56 & 17.42 & 0.07 & 0.79 & 1.68 & 4.40 & 0.05 & 99.22 & $\begin{array}{l}\text { Black, } \\
\text { homog. }\end{array}$ \\
\hline 6 & 1100 & 1 & 48.84 & 0.74 & 11.88 & 8.43 & 21.12 & 0.13 & 1.80 & 0.91 & 5.23 & 0.46 & 9.54 & $\begin{array}{c}\text { Black, } \\
\text { homog. }\end{array}$ \\
\hline 7 & 1100 & 2 & 48.55 & 0.97 & 12.75 & 7.50 & 18.79 & 0.17 & 3.72 & 1.07 & 5.95 & 0.41 & 99.88 & $\begin{array}{c}\text { Black, } \\
\text { homog. }\end{array}$ \\
\hline 8 & 1100 & 4 & 51.64 & 1.47 & 7.26 & 7.37 & 22.66 & 0.12 & 3.59 & 0.90 & 4.11 & 0.56 & 99.62 & $\begin{array}{c}\text { Black, } \\
\text { homog. }\end{array}$ \\
\hline 9 & 1100 & 8 & 48.41 & 1.36 & 13.09 & 8.34 & 18.53 & 0.14 & 2.09 & 1.19 & 5.56 & 0.72 & 98.43 & $\begin{array}{c}\text { Black, } \\
\text { homog. }\end{array}$ \\
\hline 10 & 1100 & 16 & 48.59 & 0.92 & 11.90 & 10.40 & 17.52 & 0.15 & 1.79 & 1.27 & 6.15 & 0.63 & 99.32 & $\begin{array}{l}\text { Black, } \\
\text { homog. }\end{array}$ \\
\hline
\end{tabular}

From Table 2 it can be seen that the results for samples $1,2,3,4$ and 5 (all treated at $1000^{\circ} \mathrm{C}$, for a period of 1-16 $\mathrm{h}$ ) represent their poor vitrification and inhomogeneous glass composition. A lower temperature of $1000^{\circ} \mathrm{C}$ and a process duration of less than $16 \mathrm{~h}$ were not sufficient to obtain homogeneous vitreous products. Taking into account the treatment with the higher temperature $\left(1100^{\circ} \mathrm{C}\right)$ and the longest duration of the process (16h), the results of EMP analysis show that the 
main components of the obtained glass are as following: $48.6 \% \mathrm{SiO}_{2}, 11.9 \% \mathrm{Al}_{2} \mathrm{O}_{3}, 17.5 \% \mathrm{CaO}$, $10.4 \% \mathrm{FeO}^{*}, 0.9 \% \mathrm{TiO}_{2}, 1.8 \% \mathrm{MgO}, 1.3 \% \mathrm{~K}_{2} \mathrm{O}$, $6.1 \% \mathrm{Na}_{2} \mathrm{O}, 0.6 \% \mathrm{P}_{2} \mathrm{O}_{5}$ i $0.15 \% \mathrm{MnO}$. The total oxide content is $>99 \%$ by weight, while the rest are trace elements [52].

As a means of reducing the melting temperature of fly ash during municipal solid waste incineration (MSWI) and for promoting the formation of the glassy phase, in the work of Gao et al. [71], $\mathrm{B}_{2} \mathrm{O}_{3}$ was used. Ash Fusion Temperature (AFT), Atomic Absorption Spectroscopy (AAS), XRD and SEM analyses were performed. The results showed that the initial melting temperature decreased from $1211^{\circ} \mathrm{C}$ to $986^{\circ} \mathrm{C}$ with an increase in $\mathrm{B}_{2} \mathrm{O}_{3}$ content from 0 to 15 wt. $\%$.

Sintering at $600^{\circ} \mathrm{C}$, followed by vitrification of boiler (fly) ash generated in the municipal solid waste incinerator in the work of Yang et al. [30], was carried out at a temperature of $1400^{\circ} \mathrm{C}$ for one hour. After heat treatment and removal from the oven, the crucible with the melt was cooled with nitrogen gas. The resulting stable silicate slag was examined by chemical and mineralogical analyzes. The results of the leachability test according to the Dutch standard NEN 7341 show that the leaching rates of vitrified slag are significantly reduced compared to the values obtained by leaching the original ash.

In the work of Sheng [57], the application of vitrification for the treatment of borate waste from Chinese nuclear power plants was considered. Borate waste with a high content of $\mathrm{B}_{2} \mathrm{O}_{3}$ and $\mathrm{Na}_{2} \mathrm{O}$ is combined with fly ash (generated from a coal combustion power plant) in which $\mathrm{SiO}_{2}$ and $\mathrm{Al}_{2} \mathrm{O}_{3}$ occur as the main phases. Ash oxides can be used as suitable additives for vitrification of borate waste, so there is no need for additional costs of procurement of other aditives. In this work, fly ash successfully vitrified borate waste. For experimental tests of the vitrification process, samples of a mixture of borate waste and fly ash were melted in a platinum crucible at $1200^{\circ} \mathrm{C}$ for 2 hours and then annealed for 1 hour at $520^{\circ} \mathrm{C}$ in a graphite mold. Analyzes of the obtained glass showed that the glass contained $70 \mathrm{wt} \%$ of fly ash and 30 wt. $\%$ of borate waste oxides. The glasses showed good durability and adequate viscosity at $1200^{\circ} \mathrm{C}$. The results indicate the possible potential application of fly ash in the treatment of radioactive waste.

Sheng et all. [72] also examined the application of vitrification for liquid waste with a high boron content, from Korean nuclear power plants. In this investigation, the influence of the addition of glass frit on the vitrification process of liquid waste was examined, but this attempt proved unsuccessful. Using fly ash from coal-fired power plants, as in their previous work, obtained results showed that up to $30 \mathrm{wt} \%$ of waste oxides are successfully vitrified in fly ash after the addition of $5-10 \% \mathrm{Na}_{2} \mathrm{O}$ at $1200^{\circ} \mathrm{C}$.

Five different concentrations of natural $\mathrm{UO}_{2}\left(\mathrm{NO}_{3}\right)_{2} \cdot 6 \mathrm{H}_{2} \mathrm{O}$ were mixed with sufficiently dried regosol (at $100^{\circ} \mathrm{C}$ for 12 hours) by grinding in agate mortar to obtain a homogeneous soil powder contaminated with uranium in the work of Sua et al. [19]. Soil uranium concentrations were controlled at 5, 50, 500, 5000 and $50000 \mu \mathrm{g} / \mathrm{g}$. Contaminated soil was sintered in the microwave at $1400^{\circ} \mathrm{C}$ for 30 minutes. Before being completely cooled to room temperature, melts were kept in the oven for $24 \mathrm{~h}$. Characterization was performed by XRF, XRD, Nuclear Magnetic Resonance (NMR) analysis, Scanning Electron Microscopy with Energy Dispersion Analysis (FESEM-EDS) and HighResolution Transmission Electron Microscopy (HRTEM). In vitrified products, it was determined that uranium is surrounded by a three-dimensional network containing polyhedra of silicon and alumina. Obtained results indicate that microwave sintering technology for vitrification of nuclear contaminated soil is feasible and may have further application.

Concentrated radioactive elements prevent the general use of red sludge (RM) in glass-ceramics and building materials. Gold tailings (GT) have unsuitable particle sizes $(\leq 100 \mathrm{~mm})$ for use in the ceramic industry, and waste limestone (WL) contains very little lime. Due to the fact that these materials cannot be vitrified individually, Park et al. [73] examined the process of vitrification and granulation of a mixture of these materials. The process of vitrification of red sludge was investigated, with the addition of gold tailings and waste limestone as additive. Different mass ratios of red sludge, gold tailings and waste limestone were investigated in order to find the optimal composition for the production of glass beads. The results of the XRD analysis showed that the main components of the tested materials are hematite, alumina, quartz and lime.

Three samples with different contents of red sludge (RM), gold tailings (GT) and waste limestone (WL) were melted at a temperature of $1500^{\circ} \mathrm{C}$ and granulated with air. Samples A, B and $C$ were mixed in the following ratios RM:GT:WL sample A (1:2:1), sample $B(1: 1: 1)$, sample $C$ $(1: 1: 2)$. Viscous melt behavior is a key control factor which influence granulation behavior. For this reason, the viscosities of the liquid samples were measured to optimize the melt composition and granulation state. Viscosity tests of samples $A$, 
$B$ and $C$ in relation to temperature were performed. The viscosity of sample $A$ with a high content of $\mathrm{SiO}_{2}$, increases with decreasing temperature below $1500^{\circ} \mathrm{C}$ due to the polymerization of the silicate structure. The high viscosity behavior of sample A explains the poor granulation. The viscosity of sample B increased slowly with decreasing temperature to $1200^{\circ} \mathrm{C}$. Due to the fact that a wide range of granulation temperatures is available, this composition is considered optimal. Sample C containing the highest amount of $\mathrm{CaO}$ showed the lowest viscosity up to $1400^{\circ} \mathrm{C}$, resulting in smooth granulation. The granules were evaluated according to the size distribution and average sphericity. Potential for commercial production is possible thanks to the high production yield and the improved sphericity of the glass beads. Alkalinity and toxicity tests were also performed on the obtained granules. Leaching of heavy metal ions was not detected, or was below the detection limit of Inductively Coupled Plasma Optical Emission Spectroscopy (ICP-OES) analysis. The chemical stability of the granules is obviously enhanced due to the structure of the glass network obtained by the vitrification process [73].

Vitrification of hazardous mining waste and tailings from old mercury and $\mathrm{Ag}-\mathrm{Pb}$ mines in Spain has been investigated using solar technology by Navarro et al. [34]. Six samples were treated in a solar furnace, in the temperature range from $1050^{\circ} \mathrm{C}$ to $1350^{\circ} \mathrm{C}$. Leaching tests of untreated materials and treated materials were also performed. Immobilization of $\mathrm{Fe}, \mathrm{Mn}, \mathrm{Ni}, \mathrm{Cu}$ and $\mathrm{Zn}$ was achieved in samples treated at a temperature of $1350^{\circ} \mathrm{C}$, while immobilization of $\mathrm{Mn}, \mathrm{Ni}, \mathrm{Cu}$ and $\mathrm{Zn}$ was achieved in samples treated at a lower temperature of $1050^{\circ} \mathrm{C}$. Therefore, it was concluded that temperature is a very important factor for immobilization of heavy metals in soil samples when solar heating source is used, which is shown by high immobilization of metal samples treated at elevated temperatures. SEM-EDS analyzes of heat-treated samples were performed to characterize solids, especially glassy phases. It is easy to recognize the phases of the vitreous product by the vitreous texture and the presence of stains that formed as a result of the release of gaseous phases during heating. EDS analysis of the vitreous product showed the presence of $\mathrm{Si}$, $\mathrm{Ca}, \mathrm{Al}, \mathrm{Fe}, \mathrm{Mg}$ and $\mathrm{Ti}$, which could be associated with unformed silicate phases. EDS analysis could not identify metals such as $\mathrm{Pb}, \mathrm{Cu}$ and $\mathrm{V}$, because their concentrations were below the detection limit of this technique. The main mineral phases identified by XRD analysis in the samples used in the experiments with heating were quartz, barite, dolomite, calcite, illite and $\mathrm{Fe}-\mathrm{Cu}-\mathrm{As}-\mathrm{Pb}-\mathrm{Zn}$ sulfides. Also, XRD spectra showed the presence of mixtures of quartz and aluminosilicate compounds of low crystallinity (glass). In the samples treated at the highest temperature $\left(1350^{\circ} \mathrm{C}\right)$ were identified minerals such as mullite.

Iron is also present in the glass structure in the forms $\mathrm{Fe}^{3+}$ and $\mathrm{Fe}^{2+}$. The $\mathrm{Fe}^{3+} / \mathrm{Fe}^{2+}$ ratio depends on the melting conditions and the composition of the glass. Since $\mathrm{Fe}_{2} \mathrm{O}_{3}$ is an intermediate oxide in the glass structure, and $\mathrm{FeO}$ modifies the increase in the $\mathrm{Fe}^{3+} / \mathrm{Fe}^{2+}$ ratio, the viscosity increases and the mechanical properties and chemical durability improve. Iron-rich silicate mixtures, at high temperatures, are characterized by liquid-liquid phases that do not mix, which leads to the formation of a liquid phase rich in iron, which can encourage the deposition of spinel magnetite during cooling. Iron-rich glass-ceramics can also be obtained by sinter-crystallization technology, which gives the possibility of obtaining materials of complex shapes and good mechanical properties, as well as the production of tiles for paving with a very beautiful appearance. When glass powder rich in iron is thermally treated above the range of glass transformation, $\mathrm{Fe}^{2+}$ oxidation occurs to form $\mathrm{Fe}^{3+}$, which leads to variation in the chemical composition of surface and subsurface layers, affecting crystallization and leading to the formation of hematite on the surface [37]. Vitrification of hazardous waste rich in iron, generated by flotation of slag in copper production, was studied by Karamanov et al. [37]. Two glasses, containing 30 wt.\% of iron-rich waste (marked with $\mathrm{W}$ ), were melted for 30 minutes at $1400^{\circ} \mathrm{C}$. The first batch, marked as WSZ, was obtained by mixing iron-rich waste, blast furnace slag and zeolite tuff, while the second, marked as WG, was prepared by mixing iron-rich waste, broken glass, sand and limestone. By an additional heat treatment of 1 hour at $800^{\circ} \mathrm{C}$, the glass obtained from the first batch crystallized very quickly and was converted into a glassceramic material with a crystalline phase content of $60 \%$. The second glass crystallized slowly and had good sinterability. By mixing the fractions of fine and rough grains and additional crystallization by sintering at $1020^{\circ} \mathrm{C}$, granite-like glass-ceramics was obtained. A TCLP test of the initial sample of flotation waste, and samples of glass products WSZ and WG was performed, and results are shown in Table 3. Limit values for TCLP test are as followed: $0.5 \mathrm{ppm} \mathrm{Zn}, 0.2 \mathrm{ppm} \mathrm{Pb}$ and $0.1 \mathrm{ppm} \mathrm{Cu}$. The flotation waste itself must be characterized as hazardous waste, while the values of $\mathrm{Zn}, \mathrm{Cu}$ and $\mathrm{Pb}$ concentration in both obtained glasses are below the limit values and the glasses show a very high chemical durability. 
Table 3. Results of TCLP test - leached elements concentrations

Tabela 3. Rezultati TCLP testa - koncentracije izluženih elemenata

\begin{tabular}{|c|c|c|c|c|}
\hline \multirow{2}{*}{ Sample } & Batch content & \multicolumn{3}{|c|}{ Concentration (ppm) } \\
\cline { 3 - 5 } & & $\mathrm{Zn}$ & $\mathrm{Pb}$ & $\mathrm{Cu}$ \\
\hline Iron-rich waste $(\mathrm{W})$ & & $114.4 \pm 1.2$ & $7.2 \pm 0.4$ & $94.9 \pm 1.0$ \\
\hline Glass from the first batch (WSZ) & $\begin{array}{c}30 \% \text { flotation waste }+30 \% \text { blast } \\
\text { furnace slag + 40\% zeolite tuff }\end{array}$ & $0.14 \pm 0.02$ & $0.0012 \pm 0.0002$ & $<0.005$ \\
\hline $\begin{array}{c}\text { Glass from the second batch } \\
\text { (WG) }\end{array}$ & $\begin{array}{c}30 \% \text { copper flotation waste }+ \\
45 \% \text { glass cullet }+15 \% \text { quartz } \\
\text { sand }+10 \% \mathrm{CaCO}_{3}\end{array}$ & $0.17 \pm 0.02$ & $<0.001$ & $0.008 \pm 0.001$ \\
\hline
\end{tabular}

Other studies with other iron-rich glasses also have shown that vitrification significantly reduces waste leaching and that the transformation of glass into glass-ceramics with iron content further improves chemical durability [2, 15, 34, 37, 49-52].

Uruga et al. [68] examined a method that uses a liquid metal to remove a platinum group of metals $(\mathrm{Ru}, \mathrm{Rh}$, and $\mathrm{Pd})$ during a high-level radioactive waste vitrification process generated by reprocessing spent nuclear fuels. Platinum group metals are extracted in liquid metal and can be separated from molten glass as an easily separable phase. Mixtures of glass containing $\mathrm{Cu}$, radioactive waste and additives $\mathrm{SiO}_{2}, \mathrm{~B}_{2} \mathrm{O}_{3}, \mathrm{Na}_{2} \mathrm{O}$, were melted using an external and Joule heating system. Melting was performed in a tube furnace at $1200^{\circ} \mathrm{C}$ for 4 hours under an $\mathrm{Ar}$ atmosphere to prevent $\mathrm{Cu}$ from oxidizing. After glass melted, a spherical metal "button" was formed at the bottom of the furnace. These metal "buttons" can be easily separated from the vitrification of the obtained glass by crushing. Almost all Pd (93\%) was extracted with liquid copper and removed as a separable Cu-Pd metal "button" of silver color.

In a study by Chua et al. [74], the plasma vitrification process was examined on a mixture of three waste materials: fiber reinforced plastic (FRP), gill net and waste glass. To generate the plasma argon was initially used, and as the main ambient gas during the vitrification process was used air. The plasma vitrification process was performed for 1 hour at $1250^{\circ} \mathrm{C}$ with heating and cooling rates $<7^{\circ} \mathrm{C} / \mathrm{min}$. Temperature of the furnace was controlled by adjusting the plasma current, gas flow, and voltage. Following the plasma vitrification process, the vitrified product was further thermally treated with the addition of $\mathrm{Ca}(\mathrm{OH})_{2}$ as an additive to form a reusable glass-ceramic sample. Twostage post-thermal treatment was performed at high temperatures of 850 and $950^{\circ} \mathrm{C}$, which were determined by DTA analysis. Final product has a predominantly crystalline microstructure after an hour treatment. After vitrification treatment, two vitreous products were formed: one with transparent appearance due to the higher glass batch content, and other which shows the opaque and deep dark appearance.

After plasma vitrification process, the slag was characterized by SEM, XRD and ICPIAES analysis. A toxicity test (TCLP) of the obtained glass products was also performed, and obtained results indicate that the decrease in leaching rate and hardness of the obtained products increase with the amount of fiber reinforced plastic in the sample. This test proved that plasma vitrification is a sustainable technology for combustible and noncombustible waste in which the end products are in the form of inert and non-leaching slag with a reduction in volume and which can be safely disposed of [74].

Comparative studies of four treatments of fly ash generated by the combustion of municipal solid waste and their impact on the environment were performed in the work of Pei et al. [28]. Investigated treatments were: (1) plasma vitrification, including centralized treatment and plasma ex situ; (2) fuel-based vitrification in an induction furnace; (3) water washing treatment followed by rotary furnace combustion (cotreatment in the cement industry) and (4) conventional solidification and landfill disposal. The results showed that fly ash after plasma vitrification showed a large decrease in volume and mass, producing compact and strong vitreous slag, as well as that heavy metals showed a very small leaching rate. Also, organic compounds such as dioxins are destroyed due to the application of high temperatures. Regarding the toxicity to ecosystems and human health, the application of plasma vitrification technology has the smallest impact on the environment, while the application of a rotary furnace has the greatest impact. 
Lee et al. [75] vitrified the flocculate obtained from the treatment of petroleum catalyst wastewater. The flocculate was directly vitrified at $1350^{\circ} \mathrm{C}$ without the addition of any additives, and results of the XRD analysis confirmed that that is possible. The chemical durability of the vitrified product can be compared to commercial sodiumlime silicate glass, but the melting viscosity of the glass was high, so shaping and refining of the melting glass was little difficult.

\section{CONCLUSION}

Environmental pollution with various organic and inorganic substances is a problem worldwide. A large number of technologies have been developed for the remediation treatment of contaminated soil or waste, and one of them is the vitrification process. The vitrification process is an efficient method based on heat treatment of contaminated soil or waste at high temperatures, without or with the addition of additives, where the soil melts and creates a stable glass mass that has good mechanical resistance, is chemically resistant and immobilizes contaminants, preventing their further negative impact on the environment. This technique can be applied in the treatment of different types of hazardous waste, such as: radioactive waste, tailings, slag, sludge, municipal (organic) waste, dust from electric arc furnaces, fly ash, etc. Also, if the composition of some of these wastes do not completely satisfy the necessary criteria for use in the vitrification process, it is possible to combine different types of waste resulting in a stable glass or glass-ceramic product. Although the obtained glass product can be reused in industry, the remediation of contaminated soil or solid industrial waste by the vitrification process is very expensive, so this method is less commonly used.

\section{Acknowledgements}

I acknowledge the financial support of the Ministry of Education, Science and Technological development of the Republic of Serbia, Grant No. 451-03-9/2021-14/200052.

\section{REFERENCES}

[1] S. Ivković (2016) Upoznavanje sa različitim postupcima remedijacije zemljišta, TEMPUS projekat, Novi Sad.

[2] J. Ma. Rincón, P. Callejas, P.J. Sánchez-Soto, M.M. Jordán (2018) Vitrification and derived glassceramics from mining wastes containing vermiculite and lithium aluminium phosphate, Materials , 227, 86-89.
[3] T. Kaluđerović Radoičić (2010) Izučavanje mehanizama sorpcije teških metala apatitom: mogućnost primene $u$ remedijaciji zagađenog zemljišta i podzemnih voda, doktorska teza, Tehnološko-metalurški fakultet, Beograd.

[4] D. Ugrinov, A. Stojanov, Bioremedijacija u tretmanu zagađenog zemljišta (2010), Zaštita Materijala 51, broj 4, 237-244.

[5] D. Kim, A. A. Kruger, Volatile species of technetium and rhenium during waste vitrification (2018), Journal of Non-Crystalline Solids, 481, 41-50.

[6] S. Khalid, M. Shahid, N. K. Niazi, B. Murtaza, I. Bibi, C. Dumat (2017) A comparison of technologies for remediation of heavy metal contaminated soils, Journal of Geochemical Exploration 182, 247-268.

[7] X. Shu, Y. Li, W. Huang, S. Chen, C. Xu, S. Zhang, B. Li, Y. Wang, X. Wang, Q. Qing, X. Lu (2020) Solubility of $\mathrm{Nd}^{3+}$ and $\mathrm{Ce}^{4+}$ in co-doped simulated radioactive contaminated soil after microwave vitrification, Ceramics International, 46, 6767-6773.

[8] J. Iwaszko, M. Zajemska, A. Zawada, S. Szwaja, A. Poskart (2020) Vitrification of environmentally harmful by-products from biomass torrefaction process, Journal of Cleaner Production, 249, 119427.

[9] K. Moustakas, D. Fatta, S. Malamis, K. Haralambous, M. Loizidou (2005) Demonstration plasma gasification/vitrification system for effective hazardous waste treatment, Journal of Hazardous Materials $B, 123,120-126$.

[10] J. H. Heo, J. W. Cho, H. S. Park, J. H. Park (2019) Crystallization and vitrification behavior of $\mathrm{CaO}$ $\mathrm{SiO}_{2}-\mathrm{Fe}_{\mathrm{t}} \mathrm{O}-\mathrm{Al}_{2} \mathrm{O}_{3}$ slag: Fundamentals to use mineral wastes in production of glass ball, Journal of Cleaner Production, 225, 743-754.

[11] S. Ballesteros, B. Rincón-Mora, M. M. Jordán, J. M. Rincón (2019) Vitrification of a sodium chromate waste and mechanical properties of a final glassceramic, Materials Letters: X, 4, 100025.

[12] C. Tsakalou, S. Papamarkou, P.E. Tsakiridis, G. Bartzas, K. Tsakalakis (2018) Characterization and leachability evaluation of medical wastes incineration fly and bottom ashes and their vitrification outgrowths, Journal of Environmental Chemical Engineering, 6, 367-376.

[13] D. Ding, X. Song, C. Wei, J. La Chance (2019) A review on the sustainability of thermal treatment for contaminated soils, Environmental Pollution, 253, 449-463.

[14] T. Sofilić (2014) Onečišćenje i zaštita tla, Sveučilište u Zagrebu, Metalurški fakultet .

[15] P. Colombo, G. Brusatin, E. Bernardo, G. Scarinci (2003) Inertization and reuse of waste materials by vitrification and fabrication of glass-based products, Current Opinion in Solid State and Materials Science, 7, 225-239. 
[16] V. Novaković, A. Tomić, N. Nikolić, D. Petrović (2018) knjiga Zagađenje i zaštita zemljišta i podzemnih voda, Izdavač "FELJTON" DOO Novi Sad, p. 112-131.

[17] P. L. O'Brien, T. M. De Sutter, F. X. M. Casey, E. Khan, A. F. Wick (2018) Thermal remediation alters soil properties - a review, Journal of Environmental Management, 206, 826-835.

[18] C. P. Kaushik (2014) Indian Program for Vitrification of High Level Radioactive Liquid Waste, Procedia Materials Science, 7, 16-22.

[19] X. Shu, Y. Li, W. Huang, S. Chen, C. Xu, S. Zhang, B. Li, X. Wang, Q. Qing, X. Lu (2020) Rapid vitrification of uranium-contaminated soil: Effect and mechanism, Environmental Pollution, 263, 114539.

[20] Lj. M. Rajić (2010) Unapređivanje elektrokinetičke remedijacije sedimenta zagađenog teškim metalima, doktorska teza, Univerzitet u Novom Sadu Prirodno-matematički fakultet, departman za hemiju, biohemiju i zaštitu životne sredine, Novi Sad.

[21] K. H. Oma, R. K. Farnsworth, J. M. Rusin (1982) In situ vitrification: application analysis for stabilization of transuranic waste, Prepared for the U.S. Department of Energy under Contract DE-AC0676RLO 1830

[22] M. G. Byers, V. F. Fitzpatrick, R. D. Holtz, Site Remediation by In Situ Vitrification, Transportation Research Record, 1312, 162-166.

[23] M. M. Jordan, M.B. Almendro-Candel, J. NavarroPedreño, D. Guirao, A. Acosta, J. Ma. Rincón (2018) First evaluation of vitrification capability of palm tree biomass wastes and sewage sludge, Materials Letters, 229, 71-73.

[24] P. Kavouras, G. Kaimakamis, Th. A. Ioannidis, Th. Kehagias, Ph. Komninou, S. Kokkou, E. Pavlidou, I. Antonopoulos, M. Sofoniou, A. Zouboulis, C.P. Hadjiantoniou, G. Nouet, A. Prakouras, T. Kara (2003) Vitrification of lead-rich solid ashes from incineration of hazardous industrial wastes, Waste Management, 23, 361-371.

[25] H. M. S. Elgamoudi (2017) Primena fizičkih, hemijskih i bioloških metoda u ekoremedijaciji vodotoka - studija slučaja reke Drine, doktorska teza, Univezitet Singidunum fakultet za primenjenu ekologiju futura, Beograd.

[26] J. A. Menéndez, A. Domínguez, M. Inguanzo, J. J. Pis (2005) Microwave-induced drying, pyrolysis and gasification (MWDPG) of sewage sludge: Vitrification of the solid residue, Journal of Analitical and Applied Pyrolysis, 74, 406-412.

[27] F. Dellisanti, P. L. Rossi, G. Valdrè (2009) Remediation of asbestos containing materials by Joule heating vitrification performed in a pre-pilot apparatus, International Journal of Mineral Processing, 91, 61-67.

[28] S. L. Pei, T. L. Chen, S. Y. Pan, Y. L. Yang, Z. H. Sun, Y. J. Li (2020) Addressing environmental sustainability of plasma vitrification technology for stabilization of municipal solid waste incineration fly ash, Journal of Hazardous Materials, 398, 122959.
[29] G. Roth, S. Weisenburger (2000) Vitrification of high-level liquid waste: glass chemistry, process chemistry and process technology, Nuclear Engineering and Design, 202, 197-207.

[30] Y. Yang, Y. Xiao, J. H. L. Voncken, N. Wilson (2008) Thermal treatment and vitrification of boiler ash from a municipal solid waste incinerator, Journal of Hazardous Materials, 154, 871-879.

[31] P. A. Bingham, R. J. Han (2005) Vitrified metal finishing wastes I. Composition, density and chemical durability, Journal of Hazardous Materials, B119, 125-133.

[32] Z. W. Zhao, L. Y. Chai, B. Peng, Y. J. Liang, Y. He, Z. H. Yan (2017) Arsenic vitrification by copper slag based glass: Mechanism and stability studies, Journal of Non-Crystalline Solids, 466-467, 21-28.

[33] N. Barth, D. George, F. Bouyer, A. Schwartz, C. H. Lambert, S. Ahzi, Y. Remond (2020) An inverse method predicting thermal fluxes in nuclear waste glass canisters during vitrification and cooling, Nuclear Engineering and Design, 364, 110686.

[34] A. Navarro, E. Cardellach, I. Cañadas, J. Rodríguez (2013) Solar thermal vitrification of mining contaminated soils, International Journal of Mineral Processing, 119, 65-74.

[35] G. Suneel, S. Rajasekaran, J. Selvakumar, C. P. Kaushik, J. K. Gayen, K. V. Ravi (2019) Determination of reaction kinetics during vitrification of radioactive liquid waste for different types of base glass, Nuclear Engineering and Technology, 51, 746-754.

[36] M. Hujova, J. Klouzek, D. Cutforth, S. Lee, M. Miller, A. Kruger, P. Hrma, R. Pokorny (2020) Feed-toglass conversion during low activity waste vitrification, Ceramics International, 46, 9826-9833.

[37] A. Karamanov, M. Aloisi, M. Pelino (2007) Vitrification of copper flotation waste, Journal of Hazardous Materials, 140, 333-339.

[38] H. Yan, Q. Chen, G. Zhang, C. Chen, K. Shih (2020) Reevaluating the efficacy of moderate annealing in nuclear waste vitrification for sustainable high-level waste management, Journal of Cleaner Production, 268, 122155.

[39] J. Iwaszko, A. Zawada, I. Przerada, M. Lubas (2018) Structural and microstructural aspects of asbestos-cement waste vitrification, Spectrochimica Acta Part A: Molecular and Biomolecular Spectroscopy, 195, 95-102.

[40] P. Sengupta, C. P. Kaushik, G. B. Kale, D. Das, K. Raj, B. P. Sharma (2009) Evaluation of alloy 690 process pot at the contact with borosilicate melt pool during vitrification of high-level nuclear waste, Journal of Nuclear Materials, 392, 379-385.

[41] O. Pinet, J. F. Hollebecque, I. Hugon, V. Debono, L. Campayo, C. Vallat, V. Lemaitre (2019) Glass ceramic for the vitrification of high level waste with a high molybdenum content, Journal of Nuclear Materials, 519, 121-127. 
[42] Q. Wang, J. H. Yan, Y. Chi, X. D. Li, S. Y. Lu (2010) Application of thermal plasma to vitrify fly ash from municipal solid waste incinerators, Chemosphere, 78, 626-630.

[43] P. Hrma, J. V. Crum, D. J. Bates, P. R. Bredt, L. R. Greenwood, H. D. Smith (2005) Vitrification and testing of a Hanford high-level waste sample. Part 1: Glass fabrication, and chemical and radiochemical analysis, Journal of Nuclear Materials, 345, 19-30.

[44] T. Hartmann, H. Pentinghaus (2012) The ternary system palladium-rhodium-tellurium: A Study to understand phase formation in the vitrification process of high-level waste concentrates (HLWC), Journal of Nuclear Materials, 422, 124-130.

[45] S. Tan, N. Kirk, M. Marshall, O. Mc Gann, R. J. Hand (2019) Vitrification of an intermediate level Magnox sludge waste, Journal of Nuclear Materials, 515, 392-400.

[46] T. Taylor Eighmy, B. S. Crannell, J. E. Krzanowski, L. G. Butler, F. K. Cartledge, E. F. Emery, J. D. Eusden Jr, E. L. Shaw, C. A. Francis (1998) Characterization and phosphate stabilization of dusts from the vitrification of MSW combustion residues, Waste Management, 18, 513-524.

[47] P. Kavouras, Ph. Komninou, K. Chrissafis, G. Kaimakamis, S. Kokkou, K. Paraskevopoulos, Th. Karakostas (2003) Microstructural changes of processed vitrified solid waste products, Journal of the European Ceramic Society, 23, 1305-1311.

[48] C. A. Utton, R. J. Hand, P. A. Bingham, N. C. Hyatt, S. W. Swanton, S. J. Williams (2013) Dissolution of vitrified wastes in a high-pH calcium-rich solution, Journal of Nuclear Materials, 435, 112-122.

[49] T. Basegio, A. P. B. Leăo, A. M. Bernardes, C. P. Bergmann (2009) Vitrification: An alternative to minimize environmental impact caused by leather industry wastes, Journal of Hazardous Materials $165,604-611$.

[50] C. S. Ray, V. A. Samaranayake, A. Mohammadkhah, T. E. Day, D. E. Day (2017) Iron phosphate glass waste forms for vitrifying Hanford AZ102 low activity waste (LAW), part I: Glass formation model, Journal of Non-Crystalline Solids, 458, 149-156.

[51] A. Karamanov, P. Paunović B. Ranguelov, E. Ljatifi, A. Kamusheva, G. Načcevski, E. Karamanova, A. Grozdanov (2017) Vitrification of hazardous Fe-Ni wastes into glass-ceramic with fine crystalline structure and elevated exploitation characteristics, Journal of Environmental Chemical Engineering, 5, 432-441.

[52] P. Stabile, M. Bello, M. Petrelli, E. Paris, M. R. Carroll (2019) Vitrification treatment of municipal solid waste bottom ash, Waste Management, 95, 250-258

[53] S. Varitis, P. Kavouras, E. Pavlidou, E. Pantazopoulou, G. Vourlias, K. Chrissafis, A.I. Zouboulis, Th. Karakostas, Ph. Komninou (2017) Vitrification of incinerated tannery sludge in silicate matrices for chromium stabilization, Waste Management, 59, 237-246.
[54] M. Prica, (2008) Efekti primene različitih postupaka remedijacije na imobilizaciju teških metala u sedimentu, doktorska teza, Univerzitet u Novom Sadu prirodno-matematički fakultet departman za hemiju, Novi Sad.

[55] I. Ghiloufi (2009) Simulation of radioelement volatility during the vitrification of radioactive wastes by arc plasma, Journal of Hazardous Materials, 163, 136-142.

[56] I. C. Chou, Y. F. Wang, C. P. Chang, C. T. Wang, Y. M. Kuo (2011) Effect of $\mathrm{NaOH}$ on the vitrification process of waste $\mathrm{Ni}-\mathrm{Cr}$ sludge, Journal of Hazardous Materials, 185, 1522-1527.

[57] J. Sheng (2001) Vitrification of borate waste from nuclear power plant using coal fly ash, (I) Glass formulation development, Fuel, 80, 1365-1369.

[58] M. A. Langerman, R. J. Mac Kinnon (1991) Scaling considerations for modelling the in situ vitrification process, Applied Mathematical Modelling, 15, 542549 .

[59] J. Dragun (1991) Geochemistry and soil chemistry reactions occurring during in situ vitrification, Journal of Hazardous Materials, 26, 343-364.

[60] L. Liu, W. Li, W. Song, M. Guo (2018) Remediation techniques for heavy metal-contaminated soils: Principles and applicability, Science of the Total Environment, 633, 206-219.

[61] A. Goel, J. S. Mc Cloy, R. Pokorny, A. A. Kruger (2019) Challenges with vitrification of Hanford HighLevel Waste (HLW) to borosilicate glass - An overview, Journal of Non-Crystalline Solids: X, 4, 100033.

[62] C. P. Rodriguez, J. Chun, M. J. Schweiger, A. A. Kruger, P. Hrma (2014) Application of evolved gas analysis to cold-cap reactions of melter feeds for nuclear waste vitrification, Thermochimica Acta, 592, 86-92.

[63] B. J. Riley, J. V. Crum, W. C. Buchmiller, B. T. Rieck, M. J. Schweiger, J. D. Vienna (2019) Laboratory-scale quartz crucible melter tests for vitrifying a high- $\mathrm{MoO}_{3}$ raffinate waste stimulant, Progress in Nuclear Energy, 110, 13-23.

[64] C. C. Tzeng, Y. Y. Kuo, T. F. Huang, D. L. Lin, Y. J. Yu (1998) Treatment of radioactive wastes by plasma incineration and vitrification for final disposal, Journal of Hazardous Materials, 58, 207220.

[65] F. Dellisanti, P. L. Rossi, G. Valdrè (2009) In-field remediation of tons of heavy metal-rich waste by Joule heating vitrification, International Journal of Mineral Processing, 93, 239-245.

[66] P. Hrma, A.A. Kruger, R. Pokorny (2012) Nuclear waste vitrification efficiency: Cold cap reaction, Journal of Non-Crystalline Solids, 358, 3559-3562.

[67] R. Kimura, Y. Inagaki, K. Idemitsu, T. Arima (2018) Vitrification processes of simulated cesium sorbing zeolite waste, Progress in Nuclear Energy, 108, 497-502.

[68] K. Uruga, K. Sawada, Y. Enokida, I. Yamamoto (2008) Vitrification of high-level radioactive waste 
considering the behavior of platinum group metals, Progress in Nuclear Energy, 50, 514-517.

[69] J. Chun, D. A. Pierce, R. Pokorny, P. Hrma (2013) Cold-cap reactions in vitrification of nuclear waste glass: Experiments and modeling, Thermochimica Acta, 559, 32- 39.

[70] M. Hujová, J. Klouzek, D. A. Cutforth, S. M. Lee, M. D. Miller, B.Mc Carthy, P. R. Hrma, A. A. Kruger, R. Pokorný (2019) Cold-cap formation from a slurry feed during nuclear waste vitrification, Ceramics International, 45, 6405-6412.

[71] J. Gao, C. Dong, Y. Zhao, X. Hu, W. Qin, X. Wang, J. Zhang, J.Xue, X. Zhang (2020) Vitrification of municipal solid waste incineration fly ash with $\mathrm{B}_{2} \mathrm{O}_{3}$ as a fluxing agent, Waste Management, 102, 932938.
[72] J. Sheng, K. Choi, M. J. Song (2001) Vitrification of liquid waste from nuclear power plants, Journal of Nuclear Materials,. 297, 7-13.

[73] H. S. Park, J. H. Park (2017) Vitrification of red mud with mine wastes through melting and granulation process - Preparation of glass ball, Journal of NonCrystalline Solids, 475, 129-135.

[74] J. P. Chu, Y. T. Chen, T. Mahalingam, C. C. Tzeng, T. W. Cheng (2006) Plasma vitrification and re-use of non-combustible fiber reinforced plastic, gill net and waste glass, Journal of Hazardous Materials B, 138, 628-632.

[75] N. Li, Y. Tuo, H. Shen, S. Liu (2013) Vitrification of a waste water flocculate from a petroleum catalyst manufacturer, Ceramics International, 39, 86678672.

\section{IZVOD}

\section{VITRIFIKACIJA KAO METODA REMEDIJACIJE ZEMLJIŠTA}

Primenom tehnike vitrifikacije mogu se tretirati različite vrste kontaminiranog tla i opasnog otpada koji imaju negativan uticaj na životnu sredinu i zdravlje ljudi. Neki od otpada koji se mogu tretirati postupkom vitrifikacije su: radioaktivni otpad, jalovina, šljaka, mulj, komunalni (organski) otpad, prašina iz elektrolučnih peći, leteći pepeo itd. Postupak vitrifikacije zasnovan je na termičkoj obradi kontaminiranih zemljišta ili otpada na temperaturi od $1400-2000^{\circ} \mathrm{C}$, uz dodatak agenasa za vitrifikaciju, pri čemu se zemljište/otpad topi i formira stabilna amorfna masa. Proces vitrifikacije prenosi toksične elemente u amforni proizvod koji ima dobru mehaničku otpornost, hemijski je otporan i imobiliše zagađivače, sprečavajući na taj način njihov dalji negativni uticaj na životnu sredinu. U zavisnosti od lokacije procesa, vitrifikacija može biti in situ ili ex situ.

Ključne reči: vitrifikacija, kontaminirano zemljište, otpad, zaštita životne sredine.

Pregledni rad

Rad primljen: 19. 11. 2020.

Rad korigovan: 20. 05. 2021.

Rad prihvaćen: 24. 05. 2021.

Rad je dostupan na sajtu: www.idk.org.rs/casopis

(c) 2021 Authors. Published by Engineering Society for Corrosion. This article is an open access article distributed under the terms and conditions of the Creative Commons Attribution 4.0 International license (https://creativecommons.org/licenses/by/4.0/) 